\title{
Memorias de un confinamiento
}

\author{
Rubí Carreño Bolívar \\ Pontificia Universidad Católica de Chile
}

Si no canto lo que siento

Me voy a morir por dentro

He de gritarle a los vientos hasta reventar

Aunque sólo quede tiempo en mi lugar

Ya lo estoy queriendo

Ya me estoy volviendo canción

Alberto Spinetta

A la memoria de Marisol Gónzález Diaz (1963-2020)

En abril del 2020 invité a académicos y estudiantes de distintas latitudes a dejar un registro de lo que yo pensaba sería un semestre único en todos los sentidos del término. Imaginaba que a diciembre que saliera la revista, la pandemia sería un sueño olvidado en medio de la alegría de la vacuna y los reencuentros navideños. Asimismo, quería mostrar que no solo el virus viajaba rápido sino también nuestra posibilidad de reaccionar y hacer una red escrita de afectos que respondiera, letra con letra, al distanciamiento físico. Por primera vez los académicos del norte y los del sur enfrentábamos la misma vulnerabilidad y podríamos sentarnos a la mesa y compartir juntos, aunque fuera, el pan de la incerteza.

Muchas personas me contestaron que sí, inmediatamente. Otras, me dijeron que el tiempo se les iba en los cuidados de sus padres adultos mayores o de sus hijos sin escuela; en tareas administrativas imprevistas o en una docencia impartida desde la intimidad de sus casas y que hacía patente, por primera vez, la situación socioeconómica real de los estudiantes, falsamente homogenizada, en la sala de clases; dejo testimonio de todo esto. Coexistían entre nosotros, profesores y estudiantes, las ideas de sobreponerse a toda costa y realizar el trabajo a como diera lugar con la de mostrar la excepcionalidad de lo vivido y ver en ello una oportunidad para los cambios. La convocatoria para este dossier era reflexionar sobre la forma en que el confinamiento había cuestionado las prácticas, convicciones y creencias sobre la academia, en cuáles se persistían y cuáles parecían obsoletas a partir de esta experiencia radical; finalmente, se eligió el formato de ensayo universitario o 
de crónica. En el conversatorio Geopoliticas del cuerpo: escritura y pandemia en los que participamos con Diamela Eltit, Javier Guerrero, Laura Scarabelli se insistió, precisamente, en la necesidad de transformar la universidad, abrirla hacia la comunidad y no escamotear estos tiempos entre la mascarilla y la capucha.

El paraíso siempre anhelado de la vida en pijama, sin humanos alrededor y con todo el tiempo del mundo para investigar se había cumplido, solo que hasta para los espíritus más fuertes era y es difícil sobreponerse. Son demasiados muertos, infinitos desaciertos de los líderes políticos que hacen temblar aún más que el virus y un duelo profundo por ti, por mí, por cada casa. Aun así, con mayor o menor fe, hay un día después y la que escribe gasta su día confiando en el futuro. Doy infinitas gracias a los colegas y estudiantes radicados en distintas partes del mundo que se unieron a esta propuesta, así como también a quienes no pudieron hacerlo. Hay muchas formas de escribir y de abrirle paso al mañana.

Rubí Carreño Bolívar Directora de Taller de Letras 